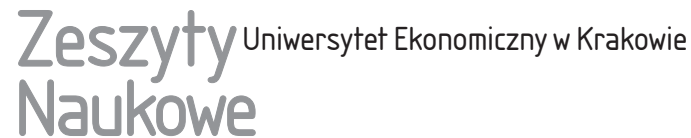

\section{Rising Income Inequalities - the Causes of and Consequences for Long-term Growth}

\begin{abstract}
Objective: The objective of the paper is to identify the channels through which income inequalities affect the short-term economic situation and long-term growth.

Research Design \& Methods: As initial research, the analysis is based on a literature review. Over the course of the review, this hypothesis was verified: inequalities have a negative impact on GDP growth rates and economic stability.

Findings: The paper explains mechanisms through which inequalities affect aggregate demand, output and accumulation, accentuating immanent threats of income disparities, such as rising debt burdens (both private and public) and current-account imbalances.

Implications/Recommendations: A policy alternative is proposed in the form of a wage-led growth strategy. This will strengthen the position of workers in the economy and thus allow the wage share to grow at least apace with productivity gains.

Contribution: The concept of wage-led growth is rarely discussed in the mainstream literature and deserves more attention.
\end{abstract}

Keywords: income inequalities, labour markets, financialisation, globalisation, economic growth.

JEL Classification: D31, J31, F36, F66, O40.

Marta Sordyl, Cracow University of Economics, Department of Macroeconomics, Rakowicka 27, 31-510 Kraków, e-mail: sordylm@uek.krakow.pl, ORCID: https://orcid.org/0000-0002-8771-2988.

This is an open access article distributed under the terms of the Creative Commons Attribution-NonCommercial-NoDerivatives 4.0 License (CC BY-NC-ND 4.0); https://creativecommons.org/ licenses/by-nc-nd/4.0/ 


\section{Introduction}

In the last few decades, income distribution has become increasingly polarised even in the developed world. Wage shares in GDP have fallen in almost all OECD countries, with real wages lagging behind productivity growth since around 1980 (Stockhammer 2013). Various factors account for the worsening situation. Anglo-Saxon countries have experienced a sharp rise in personal income inequalities, while in continental Europe the shift has occurred mainly in functional income distribution (between wages and profits). The common trend has been a rapid decline in GDP share received by non-managerial wage earners. With income distribution polarising, social inequalities have risen as well. While the problem of inequality is widely discussed in the literature on both theoretical and empirical grounds, the conclusions remain disputable.

Growing income inequalities can be analysed from three standpoints: first, on a global scale, as the divergence of per capita GDP between rich and poor countries; second, as changes in the wage- and profit-share in national income; and third, as growing disparities of compensation between different segments of the labour force. This paper focuses on within-country income inequalities, their causes and consequences for economic stability and growth. Income disparities are not just a social problem, nor do they concern only the most disadvantaged individuals; if left unchecked, they can lead to serious economic difficulties, including crises (Lavoie \& Stockhammer 2012).

The aim of the paper is to identify channels through which income inequalities affect the short-term economic situation and long-term growth. The paper is based on a review of the literature, which allows the author to verify the hypothesis that inequalities negatively affect growth rates and economic stability. Re-focusing economic strategies towards wage-led growth is an interesting alternative. The first part of the paper presents the causes of rising income disparities in developed countries - the main causes include globalisation and the financialisation of the world economy, labour-saving technological progress and the dominance of neoliberal thought in the last few decades. The second part explains mechanisms through which inequalities affect aggregate demand, output and accumulation, accentuating immanent threats of income disparities, such as rising debt burdens (both private and public) or current-account imbalances. The third part lays out institutional- and/or policy reform-based counter-measures. The last part concludes the article ${ }^{1}$.

1 The paper omits the important question of income redistribution and other policy measures influencing disposable incomes. This question deserves a separate evaluation. 


\section{Growing Income Inequalities - Main Causes}

Recent research (Stockhammer 2012, 2013, Jobs and Growth... 2013, Furceri $\&$ Loungani 2013, Cingano 2014) enables the identification of several factors affecting the distribution of income: technological innovation that changes functional income distribution (capital-augmenting technological progress increases the share of profits and the skill premium), globalisation of trade and production, demographic trends, and dominance of neoliberal ideology, which lead to stricter budgetary discipline, welfare state retrenchment and deregulation of markets, including the labour market (Jayadev 2007, World of Work Report... 2008). Stockhammer (2013) supplements the list with the increasing importance of the financial sector and capital markets, so-called "financialisation" or finace-dominated capitalism (Hein \& Mundt 2012). The first two - technological progress and continuing economic integration - are considered beneficial for the world economy as a whole, favouring some of the poorer countries and slightly lowering global income disparities. Within advanced economies, however, demand for low-skilled workers fell sharply, along with their wages, thus increasing inequalities ${ }^{2}$. As far as demographic transformation is concerned, many developing countries currently receive a demographic dividend (the number of workers grows faster than the number of dependents), while many advanced economies experience negative population growth rates and ageing. Both phenomena affect income distribution.

Standard economic theory assumes that income distribution is determined by the marginal productivity of the factors of production, with supply and demand leading to optimal outcomes in competitive markets. From that point of view, the most important determinant of income distribution is technological progress that affects productivity - and consequently the compensation - of capital and labour, both skilled and unskilled. Since at least the 1980s changes in technology, particularly the development of ICT, have been capital- and skill-biased, causing dramatic increases in personal income inequalities, especially wage differentials between skilled and unskilled workers. Low-skilled workers are substitutes for capital. That is, workers performing simple manual tasks are easily replaced by machines, while high-skilled workers are complements thereof (Pichelmann 2015). The demand for labour shifted from routine tasks, based on strict procedures which were thus easy to imitate and substitute for, to non-routine, abstract tasks requiring skills and creativity (Acemoglu \& Autor 2010), leaving unskilled workers worse off as they earned lower wages or went unemployed. This effect will probably be

\footnotetext{
2 Stockhammer (2015, p. 10) speaks outright of a "struggle between different types of labour" - between skilled and unskilled workers, on the one hand, and between employees and the unemployed on the other.
} 
larger in advanced economies, where technology is used in manufacturing as well as services, thus affecting a large part of the economy (Jobs and Growth... 2013).

The main rationale for lowering trade barriers and fostering free movement of production factors is the belief that economic integration allows for more efficient use of inputs and thus brings faster growth for all parties taking part in the exchange. Faster growth in turn leads to higher living standards and diminishes income disproportions both within and between countries. According to standard trade models, trade benefits the abundant production factor, which would be capital in developed and (low-skilled) labour in developing countries. In practice, however, globalisation has been blamed for increasing income inequalities in both groups of countries (Goldberg \& Pavcnik 2007, Author, Dorn \& Hanson 2013). It seems that lowering trade barriers does not benefit unqualified labour in poorer countries, at least not to the extent predicted by traditional theories (Boeri, Helppie \& Macis 2008). In fact, stronger competition in international trade is often a rationale for dismantling employment protection and other protective regulations, leading to lower wages (wage growth rates) and fewer non-wage benefits.

Harrison, McLaren and McMillan (2010) explore several mechanisms through which globalisation negatively affects wage distribution:

- offshoring: reallocation of production from richer to poorer countries. This includes mostly tasks that are routine (suitable for low-skilled workers) in the developed country but at the same time require relatively high skills in the developing country. The resulting changes in demand for skills increase wage differentials in both countries (in the rich country poorer workers lose jobs or earn less, while in the poorer country richer workers get better jobs and earn more);

- firm heterogeneity: the least productive firms (paying the lowest wages) suffer from imports and are forced to reduce employment and / or wages. The most successful firms expand their market share and raise profits;

- trade-induced innovation: if trade encourages innovation, it raises demand for (the highest) skills but also, consequently, wage differentials.

The overall effect of globalisation on inequalities depends to a large extent on labour and product market regulations, which favour either rent-seeking or more egalitarian income distribution. However, workers are at a strong disadvantage: since capital is much easier to move across borders than labour, capital owners can strengthen their bargaining position by threatening to relocate their production elsewhere (Stockhammer 2013). Seeking to improve competitiveness, governments also tend to favour deregulation.

An important feature of modern economies is their financialisation, which Stockhammer $(2013$, p. 7) defines as "an increased role of financial activity and rising prominence of financial institutions", noticeable in the world economy since the mid-1970s. The phenomenon encompasses short-term profit orienta- 
tion of shareholders, rising indebtedness of the private and public sector, volatile exchange rates and asset prices, etc. The impact of financialisation on the division of income is twofold. First, capital moves more freely to locations and markets that offer the highest profits, which means that firms have more investment options: financial assets, real assets, foreign assets and domestic assets. Second, the higher the importance of financial markets in the economy, the stronger the position of shareholders (managers) relative to workers; accordingly, capital share in income rises at the cost of labour (Onaran, Stockhammer \& Grafl 2011). In consequence, financialisation worsens income distribution by raising the profit share (dividends, interest payments, retained profits), but also by driving a wedge between workers' wages and management remuneration (Hein \& van Treeck 2010) 3 $^{3}$

In the broadest sense, income distribution is essentially an outcome of bargaining between firms and workers, sometimes represented by labour unions. The stronger the bargaining power of workers, the higher wages they can get; if labour demand is relatively inelastic, higher wages will lead to an increase in the wage share (Stockhammer 2013). The bargaining power of labour is often reflected in the "generosity" of the welfare state and the extent of protection accorded by employment regulations. In this context, possibly the strongest single factor contributing to the declining share of wages in developed economies is the dismantling of protective labour market institutions, which took place in the recent past, as well as tightening of fiscal policies, leading to cuts in benefits (Lavoie \& Stockhammer 2012). Changes in regulations, however, do not happen in isolation. They are strongly related to the phenomena discussed above, especially globalisation.

In globalising economies, "flexibilisation" (deregulation) of the labour market is usually recommended as a means to improving competitiveness and enhancing productivity growth, based on (some of) four arguments: rigidities slow down the process of labour reallocation from declining to developing sectors, restrictions on firing redundant workers may diminish labour-saving innovations, workers protected from dismissal may withhold effort, strengthening workers' bargaining power allows them to capture rents from productivity gains, thus discouraging firms from taking innovative risks ${ }^{4}$. For workers, however, more flexibility means less security (Auer 2007), because deregulation usually encompasses fewer restrictions on hiring and firing, liberal use of flexible forms of employment (fixed-term

${ }^{3}$ Lavoie and Stockhammer (2012, p. 22) point out another danger stemming from financialisation: "Besides contributing to the rise in income inequality, as managers and employees of the finance sector rip off bonuses of all sorts, financial deregulation has given rise to speculative episodes and, over long periods, to increasing debt levels for financial institutions and households".

${ }^{4}$ A similar case can be made for technological progress, which makes the firms' environment more dynamic and thus requires more frequent changes in employment. 
contracts, job agencies, etc.), abolishing (or restricting) minimum wages, lowering unemployment insurance and non-wage benefits.

Labour market regulations influence wage dispersion in several ways. First, centralised bargaining allows for coordinated reactions to aggregate shocks, leading to a more homogenous wage structure across firms, sectors and regions, especially when the union wage applies to non-unionised workers. Second, statutory minimum wages compress the wage distribution (by lifting its floor), as do social protection systems - generous transfers raise the reservation wage, encouraging workers to refuse the lowest-wage offers. The effect of stringent employment protection is similar: severance pay or other transfers from the firm in case of separation lower the cost of unemployment, increasing wage expectations.

IMF experts (Jobs and Growth... 2013) analysed a sample of 51 developed and developing countries over the period 1981-2003; they found an annual increase in the Gini coefficient of about 0.4 percent annually, with technology and globalisation the biggest contributors. A part of the inequality increase was offset by changes in education and in the sectoral composition of employment. The impacts of trade and financial globalisation work in opposite directions: trade liberalisation is associated with lower income inequality, while financial openness leads to higher inequality, with the main channels being the premium on skills and higher returns to capital. Stockhammer (2013) conducted a similar survey (a sample of developing and developed countries, 1990-2004) and offered the following observations: financialisation had the greatest negative impact on the compensation of workers. Both globalisation and welfare-state retrenchment lowered the wage share, while technological progress contributed to a modest increase in the share of wages. These results "suggest that income distribution is not primarily determined by technological progress, but rather depends on social institutions and on the structure of the financial system. Strengthening the welfare state, in particular changing union legislation to foster collective bargaining and financial regulation, could help increase the wage share with little if any costs in terms of economic efficiency" (Stockhammer 2013, p. 43).

\section{The Impact of Income Inequalities on Growth}

Economic theory usually treats income inequalities as an intrinsic feature of a market economy. It treats them as beneficial (insofar as they create a set of incentives for investment and efficiency) or at least harmless in terms of economic growth. The evidence mounting in recent years, however, seems to indicate that high income disparities do have negative consequences for both the economy and society. There are at least two channels through which income inequalities affect 
long-term growth: their impact on global demand, output and factor accumulation, and inherent consequences of unequal income distribution - rising indebtedness and/or permanent current account deficits, social tensions and conflicts, with potentially disastrous consequences.

Bernstein (2013) enumerates several groups of theories that link income inequalities with economic growth: supply-side and demand-side models, political economy models and models of financial bubbles. In the first case, an unequal initial distribution of resources causes unequal opportunities, which in turn leads to slower accumulation of human and physical capital. Demand-side theories focus on the impact of functional income distribution on consumption, investment and global demand. Political economy theories include links between inequalities and political incentives: highly concentrated wealth allows the privileged to mold institutions in ways that deepen and perpetuate inequalities. In the last class of models, income inequalities cause asset bubbles and other forms of economic instability that undermine long-term growth. Some examples of these theories are discussed below.

From the supply side, income inequalities can be beneficial for growth if they:

- create incentives to work harder, accumulate resources and take risks to increase returns and improve efficiency (Lazear \& Rosen 1981),

- raise total savings and increase capital accumulation, since the richer have a higher propensity to save (Bourguignon 1981).

On the other hand, unequal income distribution affects growth negatively if:

- inequalities become inacceptable for voters who start to demand more tax progression and stricter regulations, leading to lower investment (Barro 2000). In extreme cases, inequalities cause political destabilisation and social unrest (Rodrik 1999). The resulting uncertainty makes it more difficult to react to external shocks (Berg \& Ostry 2011);

- imperfect financial markets link consumption and the investment ability of an individual to her income or wealth, which means that the poorer are unable to fully realise potentially profitable investment, e.g., are forced to take an early exit from education (Galor \& Zeira 1993)

- inequalities raise fertility rates while lowering individual human capital investment: poorer families decide to augment their income by increasing household size (an effect which Ehrhart (2009) calls "a higher demand for children"), since they are unable to upgrade their skills and get higher wages. This makes human capital accumulation even more difficult for the poor, especially in developing countries, where life-time returns to skills may not be high enough to justify foregone consumption (Cervelati, Sunde \& Zimmermann 2016);

${ }^{5}$ Investment indivisibility (for instance, a given number of years of study necessary to gain a degree) exacerbates the influence of initial endowments on human capital accumulation. 
- implementation of some technological innovations requires a threshold-level of domestic demand, which in turn depends on consumption abilities of the lower social strata (Krueger 2012).

Since the net effect of the above is difficult to determine ex ante, an important role remains for regulations and economic policy - they can either moderate or exacerbate market imperfections, dispel or intensify social tensions, etc.

The impact of inequalities on the supply of labour can also affect resources. There are several mechanisms through which families can (attempt to) prevent a decline in consumption following a fall in wages or a lower wage share: an increase in individual labour supply or in family labour supply (secondary workers); gaining access to welfare programmes, where available; a decrease in savings and/or increase in borrowing to finance expenditure. According to van Treeck and Sturn (2012), household reaction to changes in income distribution also depends on access to and regulation of credit markets, regulation of the labour market (internal and external flexibility), workers' skills (specific/vocational versus general training), and the quality and accessibility of the educational system (private versus public financing). Since each strategy affects the labour supply (activity rates) differently, total effect is difficult to predict. However, some studies (e.g., Bowles and Park 2005) indicate that greater inequality is accompanied by an increase in labour supply (measured in hours of work) - apparently the lowest levels of income are not sufficient to finance consumption and households strive to diminish income disparities with longer hours and additional jobs.

The demand-side models differentiate between sources of consumer and investment demand (wages and profits) as well as the sources of financing expenditure (current income, borrowing, capital inflows). Distribution of income affects global demand through two main channels: the distribution between capital and labour on the one hand, and the distribution of income between households on the other (van Treeck \& Sturn 2012). The overall impact of changes in income distribution on aggregate demand is uncertain ex ante, since several mechanisms are at work. First, lower wage share negatively impacts consumption, because workers (especially poorer ones) have a higher propensity to consume than profit-recipients ${ }^{6}$. Second, rising profit share should encourage investment, at least at given levels of aggregate demand. Third, if lower wage share improves competitiveness, net exports will rise, possibly compensating for domestic demand. The end results thus depend on the magnitude of its components.

The most obvious channel through which income affects global demand is its impact on private consumption. Household income consists of earned wages and

${ }^{6}$ Some authors (Carvalho \& Rezai 2015, Palley 2015) point out that workers belonging to various strata of income distributions also differ in terms of propensity to consume - the level of income is more important than its source. 
the share of profits accruing to consumers. Conventional models of consumption do not include links between inequality of income and household expenditure. However, the "Rajan hypothesis" (Rajan 2010) posits that high inequalities cause consumer credit to expand excessively, making income polarisation one of the main causes of unsustainable debt, which can lead to a financial crisis. Asset price booms, increasing the value of collateral, coupled with deteriorating creditworthiness standards, allow poorer households to keep up their expenditure in spite of stagnating real wages. Moreover, Hein (2011, p. 2) claims that "consumption norms" rose across the income distribution, "driven by habit persistence, social visibility of consumption ('keeping up with the Joneses') and a kind of consumer arms race".

Rising indebtedness puts a different burden on various income groups. Barba and Pivetti (2009) argue that stagnating wages and welfare state retrenchment force poorer households to increase their borrowing. Wolff (2010) claims that the middle class tries to maintain their living standards in spite of lower wage share - upholding their social status is possible only by increasing debt. Kennickell's (2009) analysis for the US (1989-2007) shows a greater increase of debt (relative to income) in poorer groups: from $61 \%$ to $137 \%$ in the lower half of income distribution, and from $81 \%$ to $148 \%$ in the next four deciles; in the highest decile the ratio of debt to income rose only moderately. Hein and Mundt (2012) point out that private indebtedness is more difficult to manage than public debt because of higher average interest, a limited ability to raise income and a specific collective-action problem that households face: the government can pursue expansive policy to raise output and taxes, but there is no equivalent agent for consumers.

Unequal distribution of income and wealth poses another threat to economic stability (beyond unsustainable debt levels), this one coming from the top levels. The richest individuals receive a higher part of income and increase their savings (both in absolute terms and relative to other groups). At the same time, looking for profits, they are willing to take higher risks. Financial markets respond by creating innovative instruments and new investment opportunities, often of questionable quality (Kumhof \& Rancière 2010). A "propensity to speculate" (Stockhammer 2012), typical for the "super-rich" who have already reached limits of consumption, can improve efficiency in the short run, but resulting asset-price bubbles undermine stable growth in a longer perspective.

Political economy models usually focus on relations between policy and income distribution and redistribution; some of them, however, analyse broader consequences of growing income disparities. IMF experts (Jobs and Growth... 2013) point out some important risks stemming from lack of inclusion in economic and political spheres: distributional social conflict (political struggle for limited resources) and even open conflict (including civil war or other forms 
of violence). Acemoglu and Robinson (2012) show on numerous examples how "extractive political and economic institutions" lead to excessive inequalities, poverty, exploitation and eventually to the downfall of political regimes, including a disintegration of the state.

In their seminal paper, Bhaduri and Marglin (1990) assume that the economy can be profit-led (when a rise in profit share leads to higher demand in the short run and quicker growth in the long run) or wage-led (if a higher profit share lowers global demand and causes slower growth). Whether an economy is wageor profit-led depends on its structure, including the current income distribution, profit-elasticity of investment, the susceptibility of net exports to terms of trade and exchange rate volatility, the shares of consumption, investment, government expenditure and net exports in GDP. In most cases domestic demand will be wage-led, because consumption reacts more strongly than investment to changes in the wage-profit relation. This means that global demand can be profit-led only when a lower wage share raises net exports sufficiently to overbalance the fall in domestic demand, which is probable only in small open economies (Stockhammer 2015). Since the global economy as a whole is a closed system and net exports sum to zero, the global economy necessarily is wage-led.

Pursuing pro-capital policies (e.g., labour market deregulation) in a wage-led economy causes demand shortages that have to be made up for. Stockhammer (2012) identifies two main demand-supplementing strategies that have arisen in developed economies since 1980, both of which are forms of "capitalism under financialisation": debt-led (USA, Great Britain) and export-led (China, Germany). They allow their respective practitioners to compensate for lower domestic demand by credit-financed consumption and investment booms or by expanding exports. However, they also raise important risks - of accumulating debt in the first case, and of a permanently imbalanced current account in the second. An alternative worth considering is instead implementing pro-labour policies, which allow wage-led economies to achieve stable growth ${ }^{7}$.

7 This situation is succinctly summed up by Lavoie and Stockhammer (2012, p. 24): "if all countries pursue pro-labour distributional policies simultaneously, even countries that are profit-led will experience increases in aggregate demand, their economic activity being driven up by faster growth abroad. This can be contrasted to a situation where all countries are pursuing an export-led strategy: it is clear that only half of them can be successful, as all countries cannot be simultaneously net exporters". 


\section{Wage-led Growth for Promoting Inclusion, Equality and Stable Growth}

As stated above, globalisation and technological progress have made labour demand more volatile and workers less secure in terms of both employment stability and wages. It is difficult to disagree with IMF experts (Jobs and Growth... 2013, p. 4) when they stress that "job creation and inclusive growth are imperatives that resonate today in every country in the world - be it small, large, advanced, emerging, developing, post-conflict, or resource rich". Inclusive growth must be high and sustained in order to reduce poverty; it is also of crucial importance to fairly share the effects of growth between capital, labour and different groups of workers. For growth to be inclusive, it should provide productive employment, equal opportunities for all segments of the society and an effective redistribution scheme, supporting the poor and the vulnerable.

An approach taking into account the above postulates is based on a higher (increasing) share of wages in national income. The so-called wage-led growth (WLG) strategy "aims at establishing a full-employment growth model in which sustained wage growth drives demand growth via consumption growth and via the accelerator effects of investment growth as well as productivity growth via labour-saving induced technological change" (Stockhammer 2015, p. 6). According to Palley (2011), the essence of a wage-led approach is to rebuild the link between wages and productivity growth that has been severed in the last few decades, when improvements in efficiency did not translate into adequate wage increases. In the medium run, WLG strategy benefits capital owners as well as workers, at least in absolute terms (i.e., higher profits despite the higher wage share). This idea is not new - it draws on the Keynesian concept of wage increases having expansionary effects. For most households, wages are the main source of income; since poorer households tend to have a higher propensity to consume than the rich, an increase in wage share raises consumption expenditure and total domestic demand. Higher demand means growing output and employment, which in turn encourages real investment and fosters further improvements in productivity, and so forth.

In the last few decades, neoliberal reforms strengthened the position of capital and increased the share of profits at the expense of labour and wages; remedying the situation means applying the opposite logic to that of neoliberalism - or one that is at least strongly dissimilar to it. Necessary changes for WLG strategy include:

- strengthening the regulation of markets, most importantly the labour market,

- reintroducing the welfare state through income redistribution and social policies, 
- curtailing the highest incomes (top management compensation, dividends, interest) in favour of a rising minimum wage,

- rebuilding collective bargaining.

Unfortunately "all of these policies go against orthodox economic wisdom" (Lavoie \& Stockhammer 2012, p. 24), at least as expressed in the so-called Washington consensus of deregulation, privatisation and prudent macroeconomic policies.

Koske, Fournier and Wanner (2012) enumerate a number of policies that can result in the dual goals of reducing inequality and fostering growth being achieved ${ }^{8}$. Of foremost importance among these policies are those which facilitate participation in education and training, reducing the dependency of human capital accumulation on individual income, wealth, social background or area of residence. Especially policies that promote equal access to upper-secondary and tertiary education are successful in lowering inequalities and breaking the poverty trap. Another important area for improvement is the regulatory gap between "typical" (permanent) employment and other forms of contract. Reducing this dualism can lower income disparities through a more compressed wage structure and lower the risk of workers (especially the most vulnerable groups - youths, migrants, women, the elderly) getting trapped in temporary employment, with difficult access to social insurance. A similar case can be made for eliminating gender inequalities both in terms of wages and employment opportunities (e.g., providing child care).

The WLG strategy requires measures going beyond the labour market. This would include, most importantly, the re-regulation of financial markets in ways conducive to real investment and output growth. Hein and Mundt (2012) put forth a list of necessary reforms: increasing financial transparency, discouraging excessive risk-taking and punishing fraud, replacing private rating agencies with independent public ones (since ratings can be treated as a public good), increasing the role of the public sector in finance and banking (especially in investment banking), providing incentives for shareholders and managers to focus more on the long- instead of short-term strategy. By curbing financialisation and curtailing speculative profits, these changes would increase the wage share in income.

${ }^{8}$ Redistributive policies are an effective way of reducing inequalities, but more problematic in terms of efficiency and growth. While social support directly reduces disproportions in disposable income, it also has an indirect impact through higher reservation wages at the bottom of wage distribution. However, if generous benefits discourage the search for work, they can widen income gaps between workers and non-workers. To avoid this problem, benefit systems should be supported by prudent active labour market policies. When tax policy is concerned, it should be remembered that taxes affect not only disposable (after-tax) income but also decisions determining pre-tax income, such as labour supply (the choice between work and leisure) and labour demand (the total cost of labour for employers). 
An important feature of the global economy is the dense web of connections between countries and markets. Globalisation makes the wage-led strategy more difficult to implement since it requires effort from all trading partners. The global dimension of inequalities (both within countries and between them) necessitates policy coordination and cooperation to avoid inefficient, piecemeal reforms and, more importantly, the "race to the bottom" (Boix 2011) resulting from attempts to improve competitiveness.

\section{Conclusion}

A few decades ago "neoliberalism came with the promise that deregulation of goods markets, labour markets and financial markets would lead to higher growth and increased welfare. Higher inequality was to be accepted because it was said to yield economic benefits. (...) But neoliberalism has failed to deliver on its promise" (Lavoie and Stockhammer 2012, p. 22). Deregulation did in fact contribute to higher inequalities, but the benefits in terms of growth did not materialise. There are three main reasons for this. Firstly, unequal income distribution creates unequal opportunities: poorer segments of the labour force cannot pursue all profitable investment, which leaves them with lower skill-levels than they otherwise might achieve and makes improving efficiency more difficult. Secondly, most of the developed economies turned out to be wage- rather than profit-led, which has led diminishing wage shares in income to lower global demand. Stagnating demand, in turn, weakens the incentives firms have to invest in physical capital. Finally, income disparities encourage both ends of the distribution to take excessive risks: the poorer run up debt beyond their ability to repay, while the wealthier provide necessary liquidity, looking for ways to make profit on their savings, resulting in asset-price bubbles and, eventually, financial crises.

Since neoliberalism apparently leads to a dead end, an alternative worth considering is a wage-led growth strategy - strengthening the position of workers in the economy and thus allowing the wage share to grow at least on a par with productivity gains. By providing a stable source of internal demand, this strategy enables most of the traps stemming from financialisation to be avoided. Additionally, if the world economy actually is wage-led, the strategy will prove beneficial for capital owners as well. Implementing the WLG strategy requires some changes in economic policy.

Successfully introducing the WLG strategy requires that two conditions - simple to formulate but difficult to implement - be met. The first is the re-formulation of more traditional ways of thinking about economy and regulation. The second is international cooperation or at least the coordination of efforts. 


\section{Bibliography}

Acemoglu, D., Autor D. H. (2010), Skills, Tasks and Technologies: Implications for Employment and Earnings, NBER Working Papers no 16082, National Bureau of Economic Research.

Acemoglu D., Robinson J. (2012), Why Nations Fail, Crown Publishers, New York.

Agell J. (1999), On the Benefits from Rigid Labour Makets: Norms, Market Failures, and Social Insurance, "The Economic Journal", vol. 109, no 453, https://doi. org/10.1111/1468-0297.00406.

Auer P. (2007), Security in Labour Markets: Combining Flexibility with Security for Decent Work, "Economic and Labour Market Papers", no 2007/12, ILO, Geneva.

Autor D. H., Dorn D., Hanson G. H. (2013), The China Syndrome: Local Labor Market Effects of Import Competition in the United States, "American Economic Review", vol. 103, no 6, https://doi.org/10.1257/aer.103.6.2121.

Barba A., Pivetti M. (2009), Rising Household Debt: Its Causes and Macroeconomic Implications - A Long-period Analysis, "Cambridge Journal of Economics", vol. 33, no 1, https://doi.org/10.1093/cje/ben030.

Barro R. J. (2000), Inequality and Growth in a Panel of Countries, "Journal of Economic Growth", vol. 5, no 1.

Berg A. G., Ostry J. D. (2011), Inequality and Unsustainable Growth: Two Sides of the Same Coin?, IMF Staff Discussion Note, SDN/11/08, April.

Bernstein J. (2013), The Impact of Inequality on Growth, Center for American Progress, https://www.americanprogress.org/wp-content/uploads/2013/12/BerensteinInequality. pdf (access: 6.11.2016).

Bhaduri A., Marglin S. A. (1990), Unemployment and the Real Wage: The Economic Basis for Contesting Political Ideologies, "Cambridge Journal of Economics", vol. 14, no 4, https://doi.org/10.1093/oxfordjournals.cje.a035141.

Boeri T., Helppie B., Macis M. (2008), Labor Regulations in Developing Countries: A Review of Evidence and Directions for Future Research, SP Discussion Paper, no 0833 , October.

Boix C. (2011), Redistribution Policies in a Globalized World (in:) Making Globalization Socially Sustainable, eds M. Bacchetta, M. Jansen, International Labour Organization and World Trade Organization, Geneva.

Bourguignon F. (1981), Pareto Superiority of Unegalitarian Equilibria in Stiglitz' Model of Wealth Distribution with Convex Saving Function, "Econometrica", vol. 49, no 6, https://doi.org/10.2307/1911412.

Bowles S., Park Y. (2005), Emulation, Inequality and Work Hours: Was Thorsten Veblen Right?, "The Economic Journal”, vol. 115, no 507, https://doi.org/10.1111/j.14680297.2005.01042.x.

Carvalho L., Rezai A. (2015), Personal Income Inequality and Aggregate Demand, "Cambridge Journal of Economics", vol. 40, no 2, https://doi.org/ 10.1093/cje/beu085.

Cervellati M., Sunde U., Zimmermann K. F. (2016), Demographic Dynamics and Long-run Development: Insights for the Secular Stagnation Debate, ZEF Discussion Papers on Development Policy, no 226, September.

Cingano F. (2014), Trends in Income Inequality and Its Impact on Economic Growth, OECD Social, Employment and Migration Working Paper no 163, OECD Publishing.

Ehrhart C. (2009), The Effects of Inequality on Growth: A Survey of the Theoretical and Empirical Literature, ECINEQ WP 2009-107, February. 
Furceri D., Loungani P. (2013), Who Let the GINI Out?, "Finance \& Development", vol. 50 , no 4.

Galor O., Zeira J. (1993), Income Distribution and Macroeconomics, "Review of Economic Studies", vol. 60, no 1, https://doi.org/10.2307/2297811.

Goldberg P. K., Pavcnik N. (2007), Distributional Effects of Globalization in Developing Countries, "Journal of Economic Literature", vol. 45, no 1, https://doi.org/10.1257/ jel.45.1.39.

Harrison, A., McLaren J., McMillan M. S. (2010), Recent Findings on Trade and Inequality, NBER Working Papers, no 16425, National Bureau of Economic Research.

Hein E. (2011), Finance-dominated Capitalism, Re-distribution, Household Debt and Financial Fragility in a Kaleckian Distribution and Growth Model, MPRA Paper, no 34115 , October.

Hein E., Mundt M. (2012), Financialisation and the Requirements and Potentials for Wage-led Recovery - a Review Focusing on the G-20, Conditions of Work and Employment Series, no 37, ILO, Geneva.

Hein E., Treeck T. van (2010), 'Financialisation' in Post-Keynesian Models of Distribution and Growth - a Systematic Review (in:) Handbook of Alternative Theories of Economic Growth, ed. M. Setterfield, Edward Elgar, Cheltenham.

Jayadev A. (2007), Capital Account Openness and the Labor Share of Income, "Cambridge Journal of Economics", vol. 31, no 3, https://doi.org/10.1093/cje/bel037.

Jobs and Growth: Analytical and Operational Considerations for the Fund (2013), IMF, https://www.imf.org/external/np/pp/eng/2013/031413.pdf (access: 7.05.2016).

Kennickell A. (2009), Ponds and Streams: Wealth and Income in the U.S., 1989 to 2007, Finance and Economic Discussion Series, Federal Reserve Board, 2009-13.

Koske I., Fournier J., Wanner I. (2012), Less Income Inequality and More Growth - Are They Compatible? Part 2. The Distribution of Labour Income, OECD Economics Department Working Paper, no 925, OECD Publishing, Paris.

Krueger A. B. (2012), The Rise and Consequences of Inequality in the United States, https://www.whitehouse.gov/sites/default/files/krueger_cap_speech_final_remarks.pdf (access: 25.10.2016).

Kumhof M., Rancière R. (2010), Inequality, Leverage and Crises, IMF Working Paper, no WP/10/268, November.

Lavoie M., Stockhammer E. (2012), Wage-led Growth: Concept, Theories and Policies, Conditions of Work and Employment Series, no 41, ILO, Geneva.

Lazear E. P., Rosen S. (1981), Rank-order Tournaments as Optimum Labor Contracts, "Journal of Political Economy", vol. 89, no 5, http://doi.org/10.1086/261010.

Onaran O., Stockhammer E., Grafl L. (2011), Financialization, Income Distribution, and Aggregate Demand in the US, "Cambridge Journal of Economics", vol. 35, no 4, https://doi.org/10.1093/cje/beq045.

Palley T. (2011), The Economics of Wage-led Recovery: Analysis and Policy Recommendations, "International Journal of Labor Research", vol. 3, no 2.

Palley T. (2015), The Middle Class in Macroeconomics and Growth Theory: A Three-class Neo-Kaleckian-Goodwin Model, "Cambridge Journal of Economics", vol. 39, no 1, https://doi.org/10.1093/cje/beu019.

Pichelmann K. (2015), When 'Secular Stagnation' Meets Piketty's Capitalism in the 21 $11^{\text {st }}$ Century. Growth and Inequality Trends in Europe Reconsidered, European Commission Economic Papers, no 551, July. 
Rajan R. (2010), Fault Lines: How Hidden Fractures Still Threaten the World Economy, Princeton University Press, Princeton.

Rodrik D. (1999), Where Did All the Growth Go? External Shocks, Social Conflict, and Growth Collapses, "Journal of Economic Growth", vol. 4, no 4.

Stockhammer E. (2012), Rising Inequality as a Root Cause of the Present Crisis, Working Paper, no 282, Political Economy Research Institute, University of Massachusetts.

Stockhammer E. (2013), Why Have Wage Shares Fallen? A Panel Analysis of the Determinants of Functional Income Distribution, Conditions of Work and Employment Series, no 35, ILO, Geneva.

Stockhammer E. (2015), Wage-led Growth, https://www.socialeurope.eu/wp-content/ uploads/2015/04/RE5-Stockhammer.pdf (access: 4.07.2016).

Treeck T. van, Sturn S. (2012), Income Inequality as a Cause of the Great Recession? A Survey of Current Debates, Conditions of Work and Employment Series, no 39, ILO, Geneva.

Wolff E. (2010), Recent Trends in Household Wealth in the United States: Rising Debt and the Middle-class Squeeze - An Update to 2007, Levy Economics Institute Working Paper, no 589.

World of Work Report 2008. Income Inequalities in the Age of Financial Globalization (2008), ILO, Geneva.

\section{Rosnące nierówności dochodu - przyczyny i wpływ na długookresowy wzrost (Streszczenie)}

Cel: Celem artykułu jest określenie kanałów, poprzez które nierówności dochodu wpływają na krótkookresową sytuację gospodarczą oraz wzrost w długim okresie.

Metodyka badań: Artykuł jest wstępem do dalszych badań. Stanowi przegląd istniejącej literatury przedmiotu, co pozwala poddać weryfikacji hipotezę, że nierówności niekorzystnie oddziałują na stopy wzrostu oraz stabilność gospodarki.

Wyniki badań: Przedstawiono mechanizmy, poprzez które nierówności dochodu oddziałują na popyt globalny, produkcję i akumulację kapitału (rzeczowego i ludzkiego), kładąc nacisk na zagrożenia z tym związane, takie jak wzrost zadłużenia prywatnego i publicznego oraz deficyty na rachunkach obrotów bieżących.

Wnioski: Zaproponowano alternatywną strategię wzrostu opartego na płacach (wage-led growth strategy) - polega ona na wzmocnieniu pozycji pracowników w gospodarce, dzięki czemu płace rosną co najmniej w tempie odpowiadającym przyrostom wydajności. Wkład w rozwój dyscypliny: Koncepcja wzrostu opartego na płacach rzadko dyskutowana jest w literaturze głównego nurtu, zwłaszcza polskojęzycznej.

Słowa kluczowe: nierówności dochodu, rynek pracy, ufinansowienie, globalizacja, wzrost gospodarczy. 